\title{
Developing a Model for Linking Knowledge Management Systems and Intellectual Capital Measurement
}

\author{
Mário Paulo Pinto ${ }^{1}$, Maria Filomena Lopes ${ }^{2}$, Maria Paula Morais ${ }^{2}$ \\ ${ }^{1}$ ESEIG, Polytechnic Institute of Porto, Portugal \\ mariopintodeseig.ipp.pt \\ ${ }^{2}$ Portucalense University, Porto, Portugal \\ \{flopes, pmorais\}@uportu.pt
}

\begin{abstract}
Knowledge management systems (KMS) and intellectual capital (IC) measurement seek to increase the knowledge assets and the knowledge activities that bring competitive advantage to organizations. However, generally KMS ignore the IC measurement. This paper presents a model for linking these issues, showing the contribution of KMS to the IC measurement and their impact to organizations value creation. The model outlined in this paper should offer valuable guidelines to measuring the intangible assets through the knowledge wrapped in different KMS.
\end{abstract}

Keywords: Knowledge management, knowledge management systems, intellectual capital measurement.

\section{Introduction}

Today, it is widely recognized that organizational knowledge is the main source of competitive advantage and value creation. Organizations have recognised that their competitiveness is strictly related with the ability to create, store, distribute and apply their knowledge assets, in order to increase innovation, competitive advantage and future sustainability [11], [24].

IC measurement focuses the intangible assets from a strategic perspective, with the aim of showing their impact in value creation and their benefits to the organizations [42]. It covers such non-financial assets as, for instance, innovation capability, employee's creativity or customer's satisfaction, and it is oriented towards the future, focusing on the value creation and the core capabilities that bring competitive advantage. From this perspective, the IC measurement is helpful to verify the organization ability to achieve its strategic objectives. On the other hand, knowledge management $(\mathrm{KM})$ focuses mainly on managing organizational knowledge with the aim of maximize knowledge-related effectiveness. In this context, KMS play an important role by supporting and enhancing the organizational processes of knowledge creation, storage and retrieval, distribution and application [1], [22]. However, KMS and IC measurement are generally viewed in a separate way, without connections and linkages [40]. The existing KMS normally don't produce IC 
indicators, creating a gap between KMS and IC measurement. According to Smith [40], this gap is one of the most critical shortcomings in the current practices of measuring and managing IC in organizations.

The purpose of this paper is to present a model to fill this gap, linking KMS and IC measurement. The model offers support to the IC measurement through KMS, showing the contribution of these systems to the value creation. It results from the reviews on IC measurement and KMS, and also from a survey conducted to one hundred of the biggest Portuguese organizations, with the aim of identifying the KMS categories used, the IC measurement practices and the metrics used to measure IC.

Research about IC measurement has produced several approaches and models over the last few years. Section two of this paper provides a brief literature review of these models. A systematization of KMS categories is made in the third section with the purpose of highlighting the different categories that are normally used to classify KMS, and section four presents the results of the survey conducted in Portuguese organizations. The model proposed in this paper is described in section five, as well as its components, the relationship between them and the measures that KMS can provide to support the IC measurement. Section six describes the model validation based on an expert panel composed by researchers and practitioners, while section seven provides some conclusions and draws some directions for future research.

\section{Intellectual Capital Measurement Models}

IC refers to intangible assets that can generate future economic benefits, i.e., value creation. Those assets are the key of competitive advantage and they are characterized by their invisibility, the difficulty in quantifying and acquiring them, without a monetary nature and without physical substance [28]. Its measurement reflects the value added by knowledge to the organizations [26], enables to monitor the performance of the knowledge assets and their related activities [32] and produces insights into how the organizations are managing, developing and using their knowledge assets [14], [24], [30], [34].

A review of IC measurement models was made with the purpose of identifying the main components used to measure IC. Table 1 summarizes these IC measurement models identifying the components specified in each one. The models describe different components like human capital, structural capital and relationship capital, as well as social capital, R\&D capital, corporate identity, environment capital or others, depending on their own characteristics. However, human, structural and relationship capital are the most referred components [2], [9], [14].

- Human capital is concerned with individual capabilities, knowledge, skills, experience and abilities to solve problems. It represents the employee's competence, attitude and intellectual agility [38]. Competences include skills and education, while attitude covers the behaviour of the employees. Intellectual agility enables to think on innovative solutions and to change practices in order to solve problems [8].

- Structural capital is concerned with systems, organizational processes, technologies, concepts and models of how business operate databases, documents, 


\section{Developing a Model for Linking Knowledge Management Systems and Intellectual \\ Capital Measurement 3}

patents, copyrights and other codified knowledge. According to Roos [38], structural capital is what remains in the company when employees go home for the night.

- Relationship capital is concerned with alliances and relationships with customers, partners, suppliers, investors and communities. It also includes brand recognition, organization image and market position. The relationship capital represents the knowledge embedded and the value added from the relationships with other entities [3].

Table 1. A systematization of IC measurement models and their main components.

\begin{tabular}{|l|c|c|c|c|c|c|c|}
\hline \multicolumn{1}{|c|}{ IC Measurement Model } & & & & & \\
& & & & & \\
\hline Balanced Scorecard [23] & & $\mathrm{X}$ & $\mathrm{X}$ & $\mathrm{X}$ & & & \\
\hline Chen, Zhu \& Xie Model [42] & $\mathrm{X}$ & $\mathrm{X}$ & $\mathrm{X}$ & $\mathrm{X}$ & & & \\
\hline Citation-Weighted Patents [7] & & & & $\mathrm{X}$ & & & \\
\hline Danish Guidelines [32] & $\mathrm{X}$ & $\mathrm{X}$ & $\mathrm{X}$ & $\mathrm{X}$ & & & \\
\hline Heng Model [18] & $\mathrm{X}$ & $\mathrm{X}$ & $\mathrm{X}$ & $\mathrm{X}$ & & & $\mathrm{X}$ \\
\hline IC Rating [13] & $\mathrm{X}$ & $\mathrm{X}$ & $\mathrm{X}$ & $\mathrm{X}$ & & & $\mathrm{X}$ \\
\hline Inclusive Valuation Methodology [29] & $\mathrm{X}$ & $\mathrm{X}$ & $\mathrm{X}$ & & & & \\
\hline Intangible Assets Monitor [41] & $\mathrm{X}$ & $\mathrm{X}$ & $\mathrm{X}$ & & & & \\
\hline Intangible Value Framework [2] & $\mathrm{X}$ & $\mathrm{X}$ & $\mathrm{X}$ & & $\mathrm{X}$ & $\mathrm{X}$ & $\mathrm{X}$ \\
\hline Intelect Model [16] & $\mathrm{X}$ & $\mathrm{X}$ & $\mathrm{X}$ & & & & \\
\hline Intellectual Capital Index [38] & $\mathrm{X}$ & $\mathrm{X}$ & $\mathrm{X}$ & $\mathrm{X}$ & & & \\
\hline Intellectual Capital Rating [21] & $\mathrm{X}$ & $\mathrm{X}$ & $\mathrm{X}$ & $\mathrm{X}$ & & & \\
\hline Intellectus [19] & $\mathrm{X}$ & $\mathrm{X}$ & $\mathrm{X}$ & $\mathrm{X}$ & $\mathrm{X}$ & $\mathrm{X}$ & \\
\hline Meritum Guidelines [31] & $\mathrm{X}$ & $\mathrm{X}$ & $\mathrm{X}$ & & & & \\
\hline Nova Model [10] & $\mathrm{X}$ & $\mathrm{X}$ & $\mathrm{X}$ & $\mathrm{X}$ & & & \\
\hline Skandia Navigator [15] & $\mathrm{X}$ & $\mathrm{X}$ & $\mathrm{X}$ & $\mathrm{X}$ & & & \\
\hline Technology Broker [9] & $\mathrm{X}$ & $\mathrm{X}$ & $\mathrm{X}$ & $\mathrm{X}$ & & & \\
\hline The 4-Leaf Model [24] & $\mathrm{X}$ & $\mathrm{X}$ & $\mathrm{X}$ & & & & \\
\hline The Value Explorer [5] & $\mathrm{X}$ & $\mathrm{X}$ & & $\mathrm{X}$ & & & \\
\hline Total Value Creation [4] & $\mathrm{X}$ & & $\mathrm{X}$ & & & & \\
\hline Value Added Intellectual Coefficient [37] & $\mathrm{X}$ & $\mathrm{X}$ & & & & & \\
\hline Value Chain Scoreboard [25] & & $\mathrm{X}$ & $\mathrm{X}$ & $\mathrm{X}$ & & & \\
\hline
\end{tabular}

A systematization of the metrics proposed by each one of the IC measurement models reviewed was also made, with the aim of identifying a set of valuable metrics to measure the intangible assets. 


\section{Knowledge Management Systems}

KMS refer to a class of information systems applied to manage the organizational knowledge [1]. They are based on information technologies (IT) and focused on supporting the organizational processes of knowledge creation, storage and retrieval, distribution and application [1]. Their main purpose is to enable an environment that facilitates the creation and usage of knowledge, and also the communication and collaboration among the organization.

Many authors have written about the use of various types of KMS [6], [12], [17], [20], [27], [33]. The classifications referred by these authors are based on different assumptions: some of them are based on technological issues, others on related functionalities; others yet join these two criteria in the same classification. On the other hand, some of those classifications don't make a clear distinction between KMS and traditional information systems [36]. The diversity of KMS classifications based on different approaches, takes us to develop a systematization of KMS categories regarding their addressed issues, capabilities and functionalities. This systematization encompasses the following KMS categories [36]:

- Business intelligence systems

- Collaboration systems (groupware)

- Competence management systems

- Corporative portals

- Document management systems

- E-learning systems

- Expert systems

- Knowledge discovery systems

- Knowledge maps

- Workflow systems

\section{KMS and IC measurement in Portuguese Organizations}

A study was conducted in Portugal based on a survey sent to one hundred of the main Portuguese organizations in May 2005, with the aim of to know the current practices of the Portuguese organizations relating KMS usage and IC measurement. The organizations were selected from an annual publication that classifies them according their value creation. The survey questionnaire was structured in three main sections:

- Organization identification: it includes the organization name and its business area.

- Knowledge management systems identification: It comprises the identification of KMS categories used in the organization. The questionnaire presents the ten KMS categories identified in the previous section and the organizations could select the adequate categories or add new ones.

- Intellectual capital metrics identification: It comprises the identification of the metrics used in the IC measurement by Portuguese organizations. The questionnaire contains a comprehensive list of qualitative and quantitative metrics, grouped by human, structural and relationship capital, resulting from an extensive 


\section{Developing a Model for Linking Knowledge Management Systems and Intellectual}

Capital Measurement 5

review of IC measurement models. This list includes 40 metrics for human capital, 71 metrics for structural capital and 33 metrics for relationship capital. However, the respondents could also complete this list, adding new IC metrics.

Fourteen valid questionnaires answers were received, corresponding to a response rate of $14 \%$. All of the respondent organizations have selected a set of KMS categories, but only seven organizations have advanced with a set of metrics for measuring IC. According to the questionnaire answers, the remaining organizations don't proceed to a systematic IC measurement.

Table 2 summarizes the various KMS categories mentioned by respondents in the questionnaire, presenting the respective occurrence rate in industry and service organizations.

Table 2. Knowledge Management systems usage in Portuguese organizations

\begin{tabular}{|l|c|c|}
\hline KMS categories & Industry & Service \\
\hline Business Intelligence & $75,0 \%$ & $50,0 \%$ \\
Knowledge Maps & $25,0 \%$ & $25,0 \%$ \\
Document Management Systems & $75,0 \%$ & $50,0 \%$ \\
Collaboration Systems (groupware) & $37,5 \%$ & $50,0 \%$ \\
Workflow systems & $62,5 \%$ & $25,0 \%$ \\
Expert Networks & $12,5 \%$ & $25,0 \%$ \\
Competence Management Systems & $75,0 \%$ & $75,0 \%$ \\
E-learning Systems & $12,5 \%$ & $50,0 \%$ \\
Knowledge Discovery Systems & $62,5 \%$ & $100,0 \%$ \\
Corporative Portals & $62,5 \%$ & $75,0 \%$ \\
\hline
\end{tabular}

Table 3 summarizes the metrics referred by respondents, grouped by IC component: human, structural and relationship capital. The symbol $\mathrm{X}$, in Table 3 , identifies the metrics selected by industry and service organizations.

Table 3. Summary of IC metrics

\begin{tabular}{|c|c|c|c|c|}
\hline & Metrics & 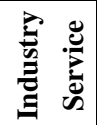 & Metrics & 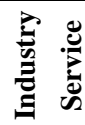 \\
\hline & $\begin{array}{l}\text { - \% Employees of full-time } \\
\text { - \% Employees of part-time } \\
\text { - \% male/female } \\
\text { - \% Specialized employees } \\
\text { - Absenteeism rate } \\
\text { - Average age of employees } \\
\text { - Average IT literacy } \\
\text { - Average of staff literacy } \\
\text { - Years on company service } \\
\text { - Average years with company } \\
\text { - Distribution by age group } \\
\text { - Employee turnover } \\
\text { - Employees alternation } \\
\text { - Experience index }\end{array}$ & $\begin{array}{ll}\mathrm{X} & \mathrm{X} \\
\mathrm{X} & \mathrm{X} \\
\mathrm{X} & \mathrm{X} \\
\mathrm{X} & \mathrm{X} \\
\mathrm{X} & \mathrm{X} \\
\mathrm{X} & \mathrm{X} \\
\mathrm{X} & \\
\mathrm{X} & \mathrm{X} \\
\mathrm{X} & \mathrm{X} \\
\mathrm{X} & \mathrm{X} \\
\mathrm{X} & \mathrm{X} \\
\mathrm{X} & \mathrm{X} \\
\mathrm{X} & \mathrm{X} \\
\mathrm{X} & \mathrm{X}\end{array}$ & $\begin{array}{l}\text { - Initiative capacity } \\
\text { - Innovation capability } \\
\text { - Investment in training per capita } \\
\text { - Leadership index } \\
\text { - Motivation index } \\
\text { - } \mathrm{N}^{\circ} \text { of employees } \\
\text { - } \mathrm{N}^{\mathrm{o}} \text { of expert employees } \\
\text { - } \mathrm{N}^{\mathrm{o}} \text { of managers } \\
\text { - Number of temporary employees } \\
\text { - Profits by employee } \\
\text { - Employees satisfaction index } \\
\text { - Time in training (days/year ) } \\
\text { - Value added per capita }\end{array}$ & $\begin{array}{ll}\mathrm{X} & \mathrm{X} \\
\mathrm{X} & \mathrm{X} \\
\mathrm{X} & \mathrm{X} \\
\mathrm{X} & \mathrm{X} \\
\mathrm{X} & \mathrm{X} \\
\mathrm{X} & \mathrm{X} \\
\mathrm{X} & \mathrm{X} \\
\mathrm{X} & \mathrm{X} \\
\mathrm{X} & \mathrm{X} \\
\mathrm{X} & \mathrm{X} \\
\mathrm{X} & \mathrm{X} \\
\mathrm{X} & \mathrm{X} \\
\mathrm{X} & \mathrm{X}\end{array}$ \\
\hline
\end{tabular}


6 Mário Paulo Pinto1, Maria Filomena Lopes2, Maria Paula Morais2

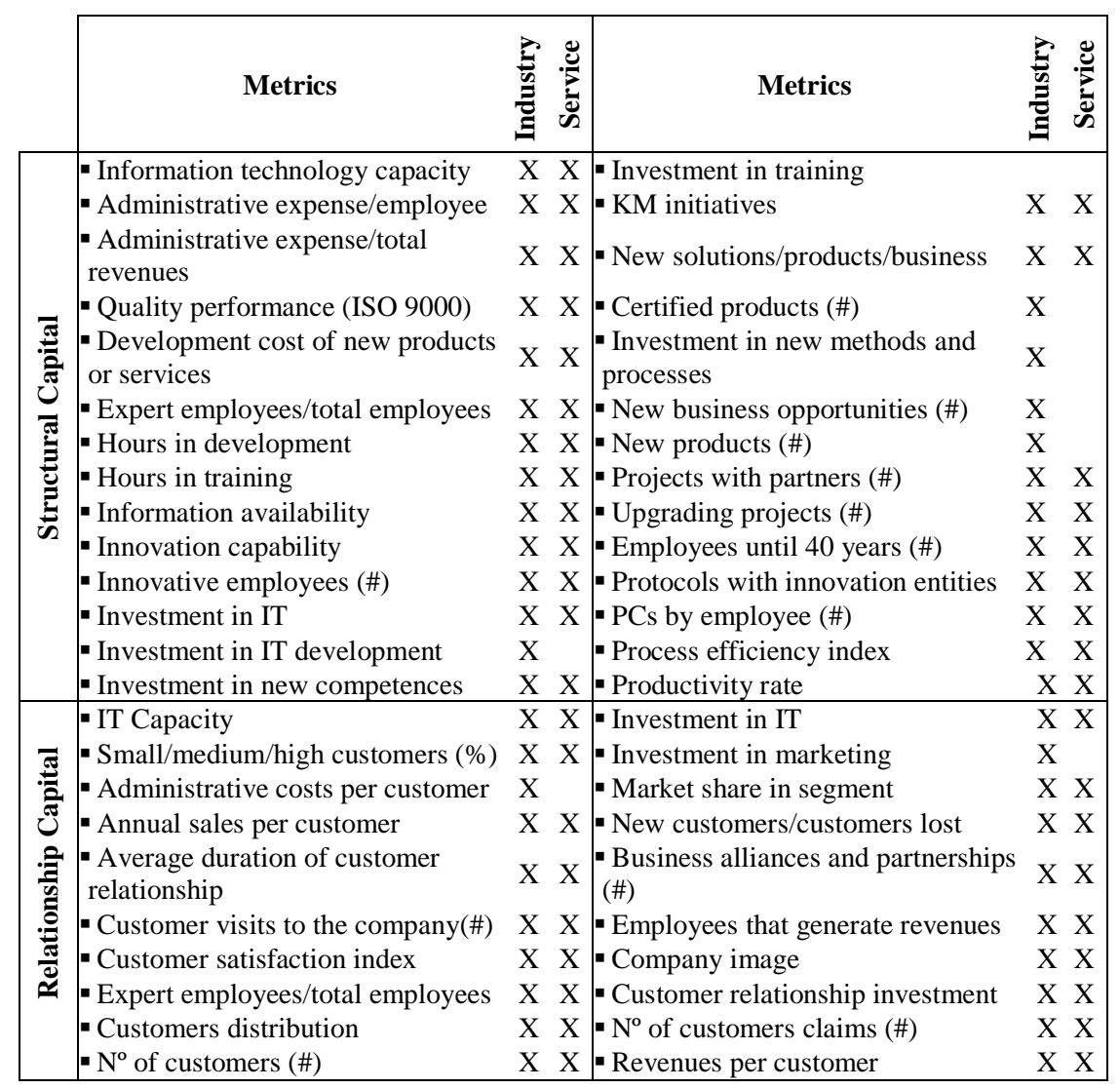

The results obtained from the survey show that there aren't strongly differences on industry and service organizations. The KMS usage and the IC metrics selected are almost the same in both business sectors.

The findings of this survey will be used in the model purposed in this paper to clarify the potential contribution of KMS in the IC measurement.

\section{A Model for Linking KMS and IC Measurement}

The main objective of the model proposed in this paper is to link KMS and IC measurement, showing the contribution of these systems to the value creation in organizations. The model can also facilitate the selection of appropriate KMS according the organization needs, aligning the KMS selection with the strategic objectives and the intangibles assets that bring competitive advantage. It provides an integrated view of intangible assets, covering the strategic and the operational perspective of KM. 


\section{Developing a Model for Linking Knowledge Management Systems and Intellectual}

Capital Measurement 7

The model is structured in three components, as is shown in Figure 1, which are: IC measurement model, knowledge management systems and IC measurement system. The objects defined in each component and the relationship between them is also described in Figure 1.

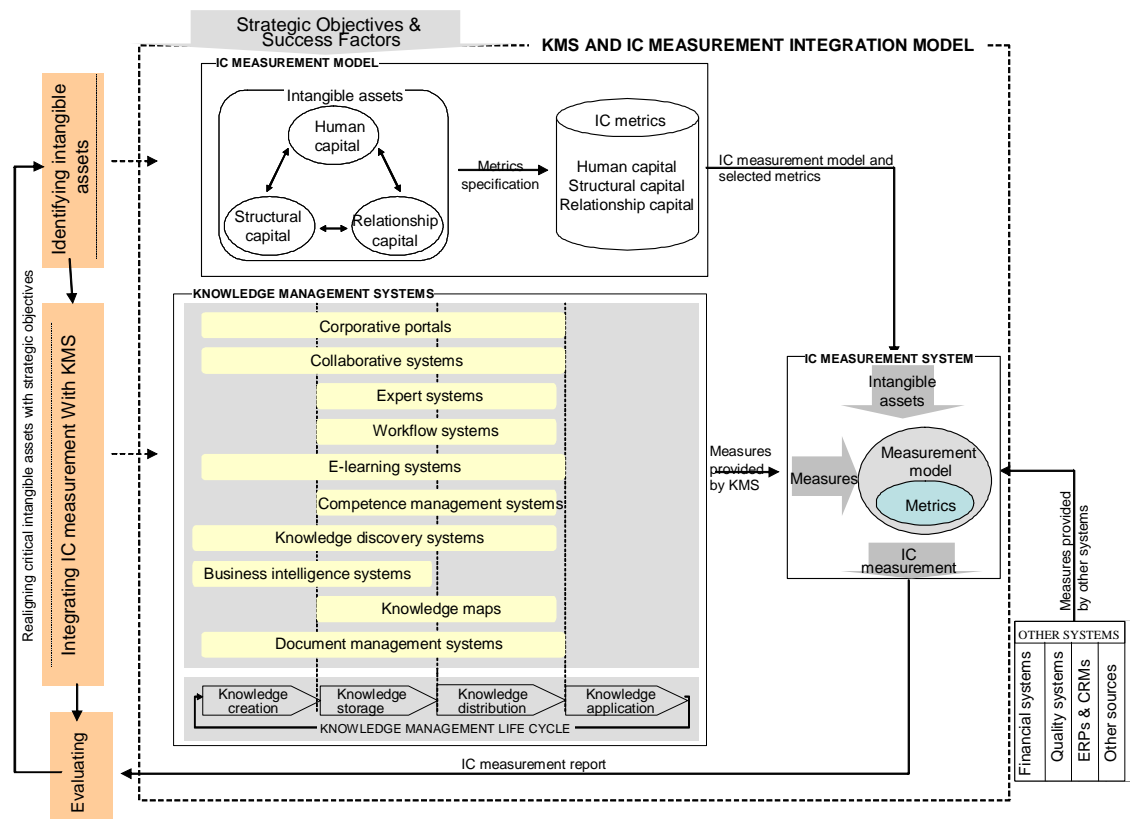

Fig. 1. A model for linking KMS and IC measurement

\subsection{The IC measurement model component}

The aim of this component comprises the identification of the intangible assets that bring competitive advantage and assure the development of the organization core competences. It also comprises the specification of appropriate metrics in order to assess these intangible assets.

The IC measurement model component starts with the identification of the mission and the corporate strategic objectives, allowing the specification of business drivers, critical success factors and the intangible assets that can create wealth to the organization. The purpose of linking IC with the strategic objectives is to ensure that the organization gets competitive advantages from its IC and KMS usage [42]. The intangible assets can be grouped in different categories, according their own characteristics: human capital, structural capital and relationship capital.

This component can be implemented through one of the reviewed IC measurement models, like for instance the Skandia Navigator, Balanced Scorecard, Intangible Assets Monitor, Intelect Model, or other. It is important to note that the model 
outlined in this paper is independent of the IC measurement model adopted, in order of not reduce their applicability.

\subsection{The knowledge management systems component}

The aim of this component is to provide a set of measures, useful to quantify the IC metrics specified in the first component of the model. KMS can offer a relevant contribute to the IC improvement, by supporting and enhancing processes related with organizational knowledge crucial to the organization [35]. However, this contribute can only be achieved if KMS are focused on the intangible assets that bring value added and competitive advantage to organizations, according their strategic objectives [42]. From this perspective, the KMS can contribute to quantify a set of metrics useful to the IC measurement through the knowledge wrapped in these systems, linking in this way the KMS and the IC measurement. This component should also facilitate the identification of the most appropriate KMS categories, according to the organization needs and strategy, and aligning the KMS selection with the intangible assets that bring competitive advantage.

This component is described in Figure 1 through a structure that represents the role performed by the different KMS categories, according their own characteristics and functionalities, in supporting KM processes, namely knowledge creation, storage, distribution and application [35]. This relationship is based on the assumption that KMS, as technological systems focused on managing the organizational knowledge, do not support knowledge application; in fact, only people are able to apply knowledge. However, the KMS could facilitate the development of an environment that enables the knowledge usage and application, from the organization people.

\subsection{The IC measurement system component}

The aim of this component is to support the IC measurement, according to the model and the metrics selected in the first component. The IC measurement system component uses a set of measures provided by the different KMS categories to quantify the specified IC metrics. It can also use some measures provided by other sources to complement the IC measurement, like for instance financial applications, quality systems or ERPs, Enterprise Resource Planning Systems.

This component establishes a linkage between the IC measurement model and the KMS, showing the contribution of the different KMS categories to the intangible assets development. The outcome of the IC measurement system consists on a report that facilitates the evaluation of intangible assets and it is a starting point to identify weaknesses and strengths in terms of organizational knowledge development. Evaluating the intangible assets can facilitate the redefinition and realignment of business drivers, success factor and intangible assets that bring competitive advantages to the organization. 
Developing a Model for Linking Knowledge Management Systems and Intellectual

Capital Measurement 9

\subsection{Measures provided by KMS to quantify IC metrics}

Each organization tries to select the most appropriate metrics to measure the intangible assets worthiness and the KM initiatives, according to their needs and their strategic objectives [39]. A wide variety of metrics are developed as an attempt to recognize and evaluate the value of intangible assets. From the literature review on IC measurement models and the survey conducted to the Portuguese organizations, it was possible to systematize the metrics more pursued in the IC measurement [36].

Considering the different KMS categories referred in this paper and their addressed issues and main functionalities, one can argue that a large number of these IC metrics could be quantified through KMS, i.e., through the knowledge wrapped in the KMS. Thus, to clarify the potential contribution of these systems to the IC measurement, a significant number of KMS were analysed, from different categories and suppliers. As a result of this study, Table 4 summarizes a set of measures that could be provided by the different KMS categories to quantify the IC metrics, clarifying the contribution of the KMS to the IC measurement.

It is also important to note that these measures could be complemented with others provided by other sources, like for instance financial systems, ERPs, CRMs, as well as survey questionnaires, as is illustrated in Figure 1.

Table 4. Measures provided to quantify IC metrics through KMS

\begin{tabular}{|c|c|}
\hline KMS & Measures provided by KMS to quantify IC metrics \\
\hline $\begin{array}{l}\text { Document } \\
\text { management } \\
\text { systems }\end{array}$ & $\begin{array}{l}\text { Accesses to organizational knowledge base (\#) } \\
\text { Contributions to organizational knowledge base (\#) } \\
\text { Time (average) to request } \\
\text { Rate of knowledge accessed/reutilized }\end{array}$ \\
\hline $\begin{array}{l}\text { Knowledge } \\
\text { maps }\end{array}$ & $\begin{array}{l}\text { Accesses to knowledge maps (\#) } \\
\text { Contributions to knowledge maps (\#) } \\
\text { Rate of knowledge accessed/reutilized }\end{array}$ \\
\hline $\begin{array}{l}\text { Collaboration } \\
\text { systems }\end{array}$ & $\begin{array}{l}\text { Projects in collaboration with external entities (\#) } \\
\text { Projects in collaborations with other workgroups (\#) } \\
\text { Rate of best practices diffusion } \\
\text { Questions reported in forums (\#) }\end{array}$ \\
\hline $\begin{array}{l}\text { Workflow } \\
\text { systems }\end{array}$ & $\begin{array}{l}\text { Processes completed without errors (\#) } \\
\text { Processes in compliance with manuals (\#) } \\
\text { Processes upgraded (\#) } \\
\% \text { of processes completed in time } \\
\% \text { of automated business processes }\end{array}$ \\
\hline $\begin{array}{l}\text { Business } \\
\text { intelligence } \\
\text { systems }\end{array}$ & $\begin{array}{l}\text { New business opportunities (\#) } \\
\text { Rate of investments in new markets } \\
\text { Market share in the segment } \\
\text { Geographic customers distribution } \\
\% \text { of new customers/customers lost } \\
\text { Rate of sales to new markets } \\
\text { Rate of sales to new customers } \\
\text { Customer satisfaction index } \\
\text { Employees satisfaction index }\end{array}$ \\
\hline
\end{tabular}


10 Mário Paulo Pinto1, Maria Filomena Lopes2, Maria Paula Morais2

\begin{tabular}{|c|c|}
\hline KMS & Measures provided by KMS to quantify IC metrics \\
\hline Expert systems & $\begin{array}{l}\text { Experts with specialization degree (\#) } \\
\text { Managers with specialization degree (\#) } \\
\text { FAQs accesses (\#) } \\
\text { Contributions from experts: rolls, best practices, advices, suggestions (\#) } \\
\text { Rate of expert knowledge accessed/reutilized } \\
\% \text { of new experts }\end{array}$ \\
\hline $\begin{array}{l}\text { Competence } \\
\text { management } \\
\text { systems }\end{array}$ & $\begin{array}{l}\text { Average time in training per employee (days per year) } \\
\text { Cost per capita in training programs } \\
\text { Average years of service in organization } \\
\text { Average age of employees } \\
\% \text { of employees by group age } \\
\% \text { of female and man employees } \\
\text { Rate of absenteeism } \\
\text { Rate of employees rotation } \\
\text { Employees satisfaction index } \\
\% \text { employees with advanced degrees } \\
\end{array}$ \\
\hline $\begin{array}{l}\text { E-learning } \\
\text { systems }\end{array}$ & $\begin{array}{l}\text { E-learning training programs (\#) } \\
\text { Hours spent in e-learning programs (\#) } \\
\% \text { employees that complete with success e-learning training programs } \\
\text { Employees with specialization based on e-learning training programs (\#) }\end{array}$ \\
\hline $\begin{array}{l}\text { Knowledge } \\
\text { discovery } \\
\text { systems }\end{array}$ & $\begin{array}{l}\text { New patents (\#) } \\
\text { Patents in registration }(\#) \\
\text { Years average of registered patents } \\
\text { Rate of knowledge reutilized in new contexts } \\
\text { New ideas to upgrade products, services or processes (\#) } \\
\text { New products, services or processes generated by innovation processes (\#) } \\
\text { Certified processes (\#) }\end{array}$ \\
\hline $\begin{array}{c}\text { Corporative } \\
\text { portals }\end{array}$ & Rate of knowledge distributed/applied \\
\hline
\end{tabular}

\section{Model Validation}

The model proposed in this paper has been evaluated by an expert panel, in order to test is validity. The point of view and the suggestions provided by the expert community can also help to improve the model in such aspects.

\subsection{Method}

Using a questionnaire, the expert panel was invited to analyse such aspects as the model completeness, coherence and comprehensiveness. The expert panel was also asked to clarify if they agree with the objects defined in the model and the suggested metrics that can be quantified through the different KMS categories. The point of view expressed by an expert community can contribute to the model validation and can also generate new ideas and new perspectives about the proposed model, contributing to the model improvement. 


\section{Developing a Model for Linking Knowledge Management Systems and Intellectual \\ Capital Measurement 11}

A questionnaire survey was sent to forty experts including researches, practitioners and consulters in the KM and KMS fields, requesting them to express their point of view about the proposed model. The questionnaire was structured in two sections: i) the first section with nine questions using a five-point scale (totally, much, little, nothing, don't know) with the aim of evaluate the model from different perspectives; ii) the second section asking the expert panel about suggestions that could be interesting to improve the model. The questionnaire was sent by email with a synthesis describing the aim of the work, the proposed model and its objects. Two follow-ups were carried with a delay of one month between them. Fourteen valid answers were received, corresponding to a response rate of $35 \%$.

\subsection{Results Discussion}

From the fourteen responses received only one was not complete, answering exclusively to the second section about suggestions to improve the model. Table 5 summarizes the questions addressed in the questionnaire and presents the occurrence rate addressed in the five-point scale for each question.

Table 5. A synthesis of the questionnaire results

\begin{tabular}{|l|c|c|c|c|c|}
\hline \multicolumn{1}{|c|}{ Questions } & Totally & Much & Little & Nothing & $\begin{array}{c}\text { Don't } \\
\text { know }\end{array}$ \\
\hline 1. Do you consider the model useful? & $46 \%$ & $54 \%$ & $0 \%$ & $0 \%$ & $0 \%$ \\
\hline 2. Do you consider the model comprehensive? & $15 \%$ & $77 \%$ & $8 \%$ & $0 \%$ & $0 \%$ \\
\hline 3. Do you consider the model complete? & $0 \%$ & $50 \%$ & $33 \%$ & $0 \%$ & $17 \%$ \\
\hline 4. Do you agree with the model components? & $8 \%$ & $84 \%$ & $8 \%$ & $0 \%$ & $0 \%$ \\
\hline \begin{tabular}{l} 
5. Do you consider the model structure coherent? \\
\hline $\begin{array}{l}\text { 6. Do you agree with the objects defined in the } \\
\text { intellectual capital measurement model component? }\end{array}$
\end{tabular} & $81 \%$ & $61 \%$ & $8 \%$ & $0 \%$ & $0 \%$ \\
\hline $\begin{array}{l}\text { 7. Do you agree with the objects defined in the } \\
\text { knowledge management systems component? }\end{array}$ & $15 \%$ & $85 \%$ & $0 \%$ & $0 \%$ & $0 \%$ \\
\hline $\begin{array}{l}\text { 8. Do you agree with the objects defined in the } \\
\text { intellectual capital measurement system component? }\end{array}$ & $8 \%$ & $84 \%$ & $8 \%$ & $0 \%$ & $0 \%$ \\
\hline $\begin{array}{l}\text { 9. Do you agree with the suggested metrics and do } \\
\text { you think it is possible to get them from KMS? }\end{array}$ & $8 \%$ & $76 \%$ & $8 \%$ & $0 \%$ & $8 \%$ \\
\hline
\end{tabular}

Based on the above statistical results, it is possible to conclude that all of the respondent experts consider the model totally or much useful. The proposed model is totally or much comprehensive for $92 \%$ of respondents, and it is complete for $50 \%$ of inquired experts. Almost all expert panel (92\%) agree totally or much with the components defined in the model and all of them consider the model structure coherent. It is also possible to conclude that almost all respondent experts $(92 \%)$ agree totally or much with the objects defined in the intellectual capital measurement model; the same result was obtained when we asked about the objects defined in the intellectual capital measurement system. On the other hand, all of the expert panel 
agree (totally or much) with the objects defined in the knowledge management systems component. Finally, 84\% of the expert panel agree (totally or much) with the suggested measures that KMS could provide to quantify the IC metrics.

The results obtained from the questionnaire show that the expert community considers the model useful, comprehensive and agree with the defined components. It is important to note that all respondents consider the model totally or much useful, which clearly indicates the utility and the relevance of this research field. The panel also agrees with the objects defined in each one of the model components. The most critical aspect focused from the expert community, in the questionnaire, was the completeness of the model. $33 \%$ of respondents have considered that the model was little complete and $17 \%$ referred that they don't know.

The second section of the questionnaire, inviting the expert community to express some suggestions to improve the model, has produced some results, described in Table 6.

Table 6. Summary of suggestions expressed by the expert community

\begin{tabular}{|c|}
\hline Suggestions \\
\hline $\begin{array}{l}\text { In addition to the comprehensive list of metrics, I would also consider softer "percentual } \\
\text { survey" measures that are critical to KM, such as the employees trust, commitment and } \\
\text { ability to share knowledge. }\end{array}$ \\
\hline $\begin{array}{l}\text { The relationship between the KMS categories and the KM processes supported by each } \\
\text { one of them is not very clear. }\end{array}$ \\
\hline $\begin{array}{l}\text { It is difficult to establish a strong relationship between the metrics and the KMS } \\
\text { quality/effectiveness. But it is a starting point and such metrics can be refined over time. }\end{array}$ \\
\hline $\begin{array}{l}\text { It is important to take into consideration some important issues, such as: the need to } \\
\text { "close the loop" through evaluation, the subjective assessment of the KMS and cultural } \\
\text { factors, like transparency and trust. }\end{array}$ \\
\hline The metrics suggested are, almost all, activity metrics and not result metrics. \\
\hline \\
\hline
\end{tabular}

Analysing these suggestions, it is possible to draw some comments:

- Almost all suggestions are related with the metrics suggested as able to be quantified through KMS. In fact, the metrics are simply suggestions and they can be redefined according to the organization context, needs and strategic objectives.

- The relationship between the KMS categories and the KM processes is not very clear probably because the synthesis sent with the questionnaire is very short. A more complete description was made in some articles [35], [36].

- The assessment of some important issues, like trust, transparency and cultural factors is important but very difficult and normally it isn't supported by KMS.

\section{Conclusion}

The complementariness between KMS and IC measurement is largely recognized, enforcing the necessity of fill the existing gap between them. The model presented in this paper is an attempt to fill this gap, showing the contribution of KMS to the IC measurement. The model establishes a relationship between the intangible assets that 


\section{Developing a Model for Linking Knowledge Management Systems and Intellectual \\ Capital Measurement 13}

bring competitive advantage and the KMS that can support the development of these assets, i.e., it facilitates the selection of the most appropriate KMS according the organization needs and strategy. On the other hand, it enables a more automated and systematic measurement of intangible assets through measures that can be provided by KMS or other systems to quantify the selected metrics.

Considering that the purposed model shows the impact of KMS in the value creation and their benefits to the organization, it contributes to evaluate the success or failure of KMS initiatives. In fact, many projects are viewed as failures or abandoned as a result of the difficulty in measuring their benefits.

Future work will focuses on the model validation through case studies.

\section{References}

1. Alavi, M. and D. Leidner: Knowledge Management and Knowledge Management Systems: Conceptual Foundations and Research Issues. MIS Quarterly, Vol. 25, № 1 (2001) 107-136

2. Allee, V.: The Value Evolution. Journal of Intellectual Capital, Vol. 1, No 1 (2000) 17-30

3. Allee, V.: "An Emerging Perspective of Wealth and Value. Research Paper", www.vernaallee.com/secondarypages/intangiblevalueframework.htm, accessed in 2004/6/12

4. Anderson and McLean: "Total Value Creation", www.totalvaluecreation.com, accessed in 2004/7/3

5. Andriessen and Tissen: Weighless Weight - Find your real value in a future of intangible assets. Pearson Education London (2000)

6. Baroni, R.: Aplicações de Softwares de Gestão do Conhecimento: tipologia e usos. UFMG University (2000)

7. Bontis, N.: There's a price to on your head: managing intellectual capital strategically. Business Quarterly, Summer (1996)

8. Bontis, N., W. Keow, et al.: Intellectual capital and business performance in Malaysian industries. Journal of Intellectual Capital, Vol. 1, No 1 (2000) 85-100

9. Brooking, A.: Intellectual Capital: Core Assets for the Third Millennium Enterprise. Thomson Business Press, London, United Kingdom (1996)

10.Camisón, Palácios, et al.: "Modelo Nova", www.gestiondelconocimiento.com, accessed in $2004 / 5 / 27$

11.Chen, Z. e. X.: Measuring Intellectual Capital: a new model and empirical study. Journal of Intellectual Capital, Vol. 5, No 1 (2004)195-212

12.Davenport, T. and L. Prusak: Working Knowledge: How Organizations Manage What They Know. Harvard Business School Press, Boston (1998)

13.Edvinsson, L.: "IC Rating", www.intellectualcapital.se, accessed in 2004/5/19

14.Edvinsson, L. and M. Malone: Intellectual Capital: Realizing your Company's True Value by Finding its Hidden Brainpower. Harper Business, New York (1997)

15.Edvinsson, L., J. Roos, et al.: Intellectual Capital: Navigating in the New Business Landscape. Mcmillan, New York (1998)

16.Euroforum: "Proyecto Intelect. Medición del Capital Intelectual", www.euroforum.es/intelect/modelo intelec.htm, accessed in 2005/2/7

17.European KM, F.: "KM Technologies and Tools IST Project $\mathrm{N}^{\circ}$ 2000-26393", www.knowledgeboard.com/library/ekmf_framework_technologiesandtools.pdf, accessed in 2004-7-14

18.Heng, M.: Mapping intellectual capital in a small manufacturing enterprise. Journal of Intellectual Capital, Vol. 2, No 1 (2001) 53-60 
14 Mário Paulo Pinto1, Maria Filomena Lopes2, Maria Paula Morais2

19.IADE and CIC: "Modelo Intellectus: Medición e Gestión del Capital Intelectual. Documento Intellectus $n^{\circ} 5 "$, www.iade.org, accessed in 2004/7/14.

20.Jackson, C.: "Process to Product: Creating Tools for Knowledge Management", www.brint.com/members/online/120205/jackson/, accessed in 4-11-2004

21.Joia, L.: Measuring Intangible Corporate Assets. Journal of Intellectual Capital, Vol. 1, № 1 (2000) 68-84

22.Kankanhalli, A. and B. Tan: A Review of Metrics for Knowledge Management Systems and Knowledge Management Initiatives. In: Proceedings of the $37^{\circ}$ Hawaii International Conference on System Sciences, Hawaii, (2004)

23.Kaplan, R. and D. Norton: The Balanced Scorecard: translating strategy into action. Harvard Business School Press, Boston, Massachusetts, USA (1997)

24.Leliaert, Candries, et al.: Identifying and managing IC: a new classification. Journal of Intellectual Capital, Vol. 4, № 2 (2003) 202-214

25.Lev, B.: Intangibles: Management, Measurement and Reporting. Brookings Institute Press, Washington DC (2002)

26.Liebowitz, J. and C. Suen: Developing knowledge management metrics for measuring intellectual capital. Journal of Intellectual Capital, Vol. 1, No 1 (2000) 54-67

27.Lindvall, M., I. Rus, et al.: Software systems support for knowledge management. Journal of Knowledge Management, Vol. 7, $\mathrm{N}^{\circ} 5$ (2003) 137-150

28.Lopes, I. and M. Martins: The New Business Models in the Knowledge Economy: the Strategic Way to Value Creation. The Electronic Journal of Knowledge Management, Vol. 4 (2006) 159-168

29.McPherson and Pike: Accounting, empirical measurement and intellectual capital. Journal of Intellectual Capital, Vol. 2, No 3 (2001) 246-260

30.Martí, J.: In Search of an Intellectual Capital General Theory. Electronic Journal of Knowledge Management, Vol. 1, Issue 2 (2003) 213-226

31.MERITUM: "Meritum Project's - Guidelines for Managing and Reporting on Intangibles", www.fek.su.se/home/bic/meritum, accessed in 2004/7/3

32.Mouritzen, J., P. Bukh, et al.: "Intellectual Capital Statements - The New Guideline", www.videnskabsministeriet.dk/fsk/publ/2003/guideline uk/html/1 0, accessed in 2004/7/23

33.Nantel, R.: Knowledge Management Tools and Technology 2004: 35 Systems to Maximize Your Organization's Intellectual and Human Capital. Brandon- hall.com, (2003)

34.Pike, S. and G. Roos: Mathematics and Modern Business Management. In:25th McMaster World Congress Managing Intellectual Capital, Hamilton, Ontário, Canadá, (2004)

35.Pinto, M., A. Lopes, et al.: A Framework for Characterizing Knowledge Management Systems. 6th European Conference on Knowledge Management, Limerick, Ireland (2005) $442-450$

36.Pinto, M., F. Lopes, et al.: Knowledge Management Systems and Intellectual Capital Measurement. Proceedings of XVI ISPIM Annual Conference, Porto, Portugal, (2005)

37.Pullic, A.: "VAIC - An Accounting Tool for IC Management", www.measuringip.at/papers/ham99txt.htm, accessed in 2004/7/3

38.Roos, J., N. Dragonetti, et al.: Intellectual Capital: Navigating in the New Business Landscape. Macmillan, New York (1997)

39.Smith, H. and J. McKeen: Developments in Practice XVII: A Framework for KM Evaluation. Communications of the Association of Information Systems (AIS), Vol. 16 (2005) 233-246

40.Smith, P.: Systemic Knowledge Management: Managing Organizational Assets for Competitive Advantage. Journal of Knowledge Management Practice, Vol. 1 (1998)

41.Sveiby, K.: "Intellectual Capital and Knowledge Management. Research paper", www.sveiby.com/articles/IntellectualCapital.htm, accessed in 2005/4/3

42.Zhou, A. and D. Fink: The Intellectual Capital Web: a systematic linking of intellectual capital and knowledge management. Journal of Intellectual Capital, Vol.4, $\mathrm{N}^{\circ} 1$ (2003) 34-48 